\title{
The Effect of Entrepreneurship Curriculum in Inculcating Entrepreneurial Intention among University Entrepreneurship Students in Kenya
}

\author{
Tabitha Wanjiru Karanja ${ }^{1}$, Gicuru Kirimi Ithinji ${ }^{2}$, Andrew B. Nyaboga ${ }^{3}$ \\ ${ }^{1}$ Department of Business Management, School of Business Management and Economic, Dedan Kimathi University of Technology, Nyeri, \\ Kenya \\ ${ }^{2}$ Department and Accounting and Finance, School of Business Management and Economics, Dedan Kimathi University of Technology, \\ Nyeri, Kenya \\ ${ }^{3}$ Accounting and Law Department, William Paterson University, Wayne, New Jersey
}

\section{Email address:}

tabbywanjiru@gmail.com (T. W. Karanja), igicuru@yahoo.com (G. K. Ithinji),nyabogaA@wpunj.edu (A. B. Nyaboga)

\section{To cite this article:}

Tabitha Wanjiru Karanja, Gicuru Kirimi Ithinji, Andrew B. Nyaboga. The Effect of Entrepreneurship Curriculum in Inculcating Entrepreneurial Intention among University Entrepreneurship Students in Kenya. Science Journal of Education.

Vol. 4, No. 2, 2016, pp. 57-64. doi: 10.11648/j.sjedu.20160402.17

Received: March 1, 2016; Accepted: March 11, 2016; Published: April 13, 2016

\begin{abstract}
This research focuses on establishing the effect of entrepreneurship curriculum in inculcating entrepreneurial intention among University students pursuing entrepreneurship degree in Kenyan Universities. Promotion of entrepreneurship has existed ever since independence. The Kenyan Government has shown tremendous support to entrepreneurship growth for instance by channeling financial support through funding such as Women Enterprise fund, Youth Enterprise Fund and Uwezo fund, Improvement of infrastructure, and the introduction of entrepreneurship education in all institutions of higher learning in accordance to sessional paper 2 of 2005. Nevertheless, youth unemployment has persistently been a major challenge in Kenya. This research purposed to investigate whether the entrepreneurship education provided in Universities does propel the youth to become entrepreneurs. Chi-square model was used to determine whether the independent variable have any influence on the dependent variable. Spearman's Rho Correlation was used to establish the degree of relationship between variables. Friedman's five point likert scale was used to measure the extent of influence between the variables. Out of 478 students, 236 were taken as a sample size out of which 212 responded. Data was then analyzed using SPSS. The findings have been reported in tables and bar charts. The researcher recommended the need for entrepreneurship curriculum to focus more on case studies, creation of partnership with prominent business, inviting business executives to deliver lectures in order for students to learn with practical examples and access role models, emphasizing technology related topics, as well as fostering an exchange program. This study concurs with previous studies that suggested that entrepreneurship education has a positive effect in inculcating entrepreneurial intention. However, curriculum developers need to consider pedagogy of entrepreneurship in Kenyan Universities in order to give it a more practical approach. Future researchers can consider the effect of entrepreneurship in Kenya polytechnics among other institutions. Chi-square model was the statistical test used in this study, future researchers may consider using regression analysis model.
\end{abstract}

Keywords: Entrepreneurship, Education, Intention

\section{Introduction}

The term entrepreneurship has been defined differently by various scholars. According to Timmons and Spinelli (2012), Entrepreneurship is the way of thinking, reasoning and acting, it is opportunity based approach and leadership balanced. Entrepreneurship results in creation enhancement, realization renewal and value not just for the owners but for stakeholders as well. Entrepreneurship is the ability to create something from practically nothing. It is initiating, doing, achieving and building an enterprise or an organization, 
rather than watching, analyzing or describing one (Kirby, 2003). Entrepreneurship has widely been accepted as a field of study that provides students with motivation, knowledge and skills which are essential for launching a successful venture (Cho, 2000).

An entrepreneur on the other hand has been defined as an individual who posses unique characteristics. Burns (2007) commented that the whole of the western world is in love affair with entrepreneurs. Entrepreneurs are looked at as economic heroes who have the ability to innovate and challenge the established equilibrium of economy and society while in the process of recreating it. In the recent years, awareness of entrepreneurship has touched almost every country in the world because of the increasing global competition based on creativity and innovation. The increased interest in entrepreneurship can also be attributed to the changing structure of the western economy, the trend to downsize large companies changing business patterns and the developing market economies especially in China, India and Eastern Europe (Kelley, 2012). The popularity of entrepreneurship has resulted in some commentaries to believe it will be the business discipline of the twenty first century in central and eastern European countries (Todorov, 2011).

The term 'currere' was first used by Pinar (Pinar, 2011). It is a Latin infinitive word for curriculum because Pinar wanted to highlight the meaning of a lived experience. The Latin word also means 'Racecourse'. For any school student, any school curriculum is a race to be run, a series of obstacles or hurdles (Subjects) to be passed. The interpretation of the word curriculum was broadening in the twentieth Century to include subjects other than the classics. Today, school documents, News paper articles, Committee reports and many academic textbooks refers to all subjects offered or prescribed by the institution as 'Curriculum of the school'. A common knowledge does exist that there is a relationship between entrepreneurship education and economic growth (European Commission, 2009). Over the years, Entrepreneurship has become an economic panacea seen as generating employment and economic propensity in both developing and developed Countries (Kuratko, 2005; Matlay, 2005; Nabi et al., 2006). In Europe for instance, small business sector has remained paramount in the success of local Communities and economic prosperity (Leyden et al., 2015).

According to (Katz, 2003), Entrepreneurship Education curriculum is best placed to equip students with the necessary knowledge and skills required to prosper in working environments (Kirby, 2002). This research went a step further and evaluated whether the curriculum is tailed towards students gaining the necessary knowledge that will make them act entrepreneurially if an enabling environment is provided. Anderson and Jack (2008) argued that entrepreneurship education is a difficult area to lecture due to its variability, complexity and contingency. The quest for entrepreneurship education has been to develop the knowledge and procedures needed in order to start and grow a successful enterprise (Gibb, 2005). Gibb recognized three main objectives that are paramount for effective entrepreneurship education. They include developing a wide understanding of an entrepreneurship, acquisition of entrepreneurial mindset, as well as how to start an enterprise effectively. According to European Commission (2009), the diversity of Entrepreneurship education provision across Europe suggests that more need to be done to encourage member states to network with one another and share expertise. Previous research has revealed that entrepreneurship education and training can influence the behavior and future attitude of students (Fayolle et al., 2007). Research has also revealed that a significant difference between students who participate in entrepreneurship education does exist in terms of propensity act (Noel, 2001).

In the United States of America, the number of universities and college with entrepreneurship curriculum has dramatically increased. In the 1960s and 1971, there were 16 colleges and universities teaching entrepreneurship. However, today there are over 800 colleges and universities with entrepreneurship class's programmers' and initiatives (Fiet, 2002). The association for advancing collegiate schools of business (A.A.C.S.B) has recently indicated that entrepreneurship will play a future role in the accreditation of academic program. A.A.C.S.B concluded a gathering for members on business schools and entrepreneurship. Its purpose being to provide programmatic guidance on how to better integrate entrepreneurship issues into missions and program of member institutions (Fiet, 2002). In China, the universities have also given attention to entrepreneurship education. The central education for China recently decided to require universities to provide a few entrepreneurship courses such as small business management, new venture creation service, industry management corporation management among others. The Chinese government hopes that such a progress would address the serious unemployment problem that the county is currently facing (Weber, 2014).

Despite all the efforts that the Government of Kenya has put in place, one of the major problems facing the Kenyan economy is unemployment. The $2005 / 2006$ economic survey revealed that youth aged between $15-19$, and 20-24 years had unemployment rate of $25 \%$ and $24 \%$ respectively. This is about double of the overall unemployment of $12.7 \%$ for the entire working group. This has mainly been contributed by corruption, nepotism and a general negative attitude toward entrepreneurship. Approximately 503,500 graduates from a pool of 1,374,360 graduates enter the job market every year. More than 870,560 graduates remain unemployed because of the weak economic performance (Nelson \& Johnson, 2004). This study is therefore within the framework of entrepreneurship intention as a strategic approach to economic growth in Kenya. One approach to enhancing entrepreneurial activity and enterprise growth in Kenya is to create an entrepreneurial culture among the Kenya youth (Nelson \& Mburungu, 2002). This is specifically important as focusing the youth as soon as they leave the university many provide a long lasting solution to the problem of unemployment in Kenya.

Kenyan Vision 2030 is the Country's development 
blueprint covering the period between 2008 and 2030. The vision aims at making Kenya an Industrialized Country. This will translate to the formulation of a middle income Country providing high quality life for its entire citizen by the year 2030. Kenya aims at increasing the annual GDP growth rate to an average of $10 \%$. The vision is quite ambitious in that it will be the only $5^{\text {th }}$ Country in the world to achieve such a high level of sustained economic growth (RoK, vision 2030). For Kenya to achieve its vision 2030, and especially the economic pillar, the emphasis on entrepreneurship is of paramount importance. Since entrepreneurs' are agents of economic change, they play a vital role in stirring the water of competition and consequently promoting economic growth. The questions addressed in this research is, how relevant entrepreneurship education program is on employment creation? How prepared are the entrepreneurship students in starting their own ventures? What is their attitude in general towards becoming future entrepreneurs? What are the barriers they foresee in their career advancement? How are they going to overcome those challenges? The purpose of this study was therefore to establish the effect of entrepreneurship curriculum in inculcating entrepreneurial intention among entrepreneurship University students in Kenya. The findings in this study would be beneficial to students pursuing entrepreneurship studies, the policy makers and curriculum developers as well as the academicians since the research brings in new knowledge and leaves a gap for further research.

\subsection{Acquisition of Entrepreneurship Mindset}

There has been a long argument whether any entrepreneur can be taught in the classroom and by extension the school. However, the general opinion is that entrepreneurs can be trained to some extent and hence acquire an entrepreneurial mindset in the classroom situation (Solomon \& Fernald, 1991). In view of the positive social and economic effect of entrepreneurship, many Kenyan Universities are advancing entrepreneurial thinking and behavior to develop student's awareness of the relevance of entrepreneurship training (Oviawe, 2010). This is meant to reiterate the massive unemployment rate in Kenyan graduates whose problem can be traced as the disequilibrium between labor market and lack of the essential employable skills by the graduates.

\subsection{Entrepreneurship Pedagogy}

According to Kuratko, (2014), the relevant question is not 'can entrepreneurship be taught "but rather "what should be taught and how should it be taught?" Oyugi (2015) identified two teaching and learning methods in entrepreneurship Education, which is "for entrepreneurship 'and 'about entrepreneurship'. The teacher of 'for entrepreneurship' tend to be more connected with the real entrepreneurial activity and are determined to make the students get near entrepreneurial experience in the form of business plan preparation, case studies, group projects and interactions with entrepreneurs. The courses about entrepreneurship tend to be taught in a traditional manner through lectures and text books.

The teaching of entrepreneurship in schools should start as early as primary school level where students are introduced to entrepreneurship and the mind set of entrepreneurship is challenged. At primary school level, a saving and investing culture when encouraged becomes critical in enhancing an entrepreneurial culture. One of the characteristics of true entrepreneurship education is that it uses methods that encourage the exercise of judgement and critical faculties of the learner.

Figure 1. The figure is used to demonstrate the multiplier effect of entrepreneurship education.

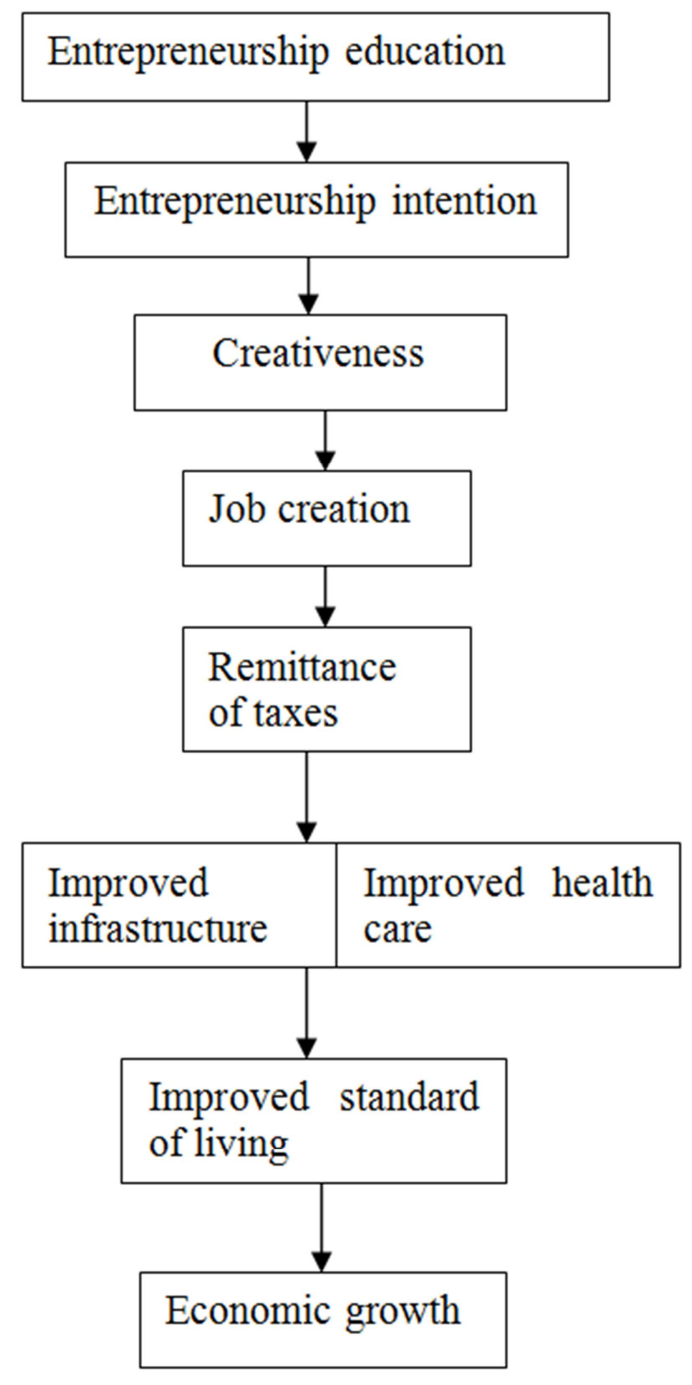

Figure 1. The Multiplier Effect of Entrepreneurship Education.

\section{Research Methodology}

\subsection{Research Design}

Kothari (2005) define a research design as the conceptual structure within which research is conducted. It is the glue that holds all elements in a research project together and is used to structure the research to show how all the major parts 
of the research project work (Kombo \& Tromp, 2006). Description on the other hand is the precise measurement and reporting of the characteristics of some population or phenomenon under study (Rubin \& Babbie, 2010). Correlation research assesses the relationships among variables with information from one variable being used to estimate variation in a related variable. In reverence to this study, the researcher intended to establish whether a relationship does exist between entrepreneurship education that has been acquired by university students for four years and their intention of becoming entrepreneurs. A list of entrepreneurship students was obtained from all Universities offering a degree in entrepreneurship and has an on-going fourth year class. Each student was assigned a random number and using simple random sampling procedure the students were issued with questionnaires.

\subsection{Population of the Study}

A population is defined as the complete set of relevant units of analysis or data (Nachmias \& Nachmias, 2008). The population of this study was university students who are in fourth year and pursing entrepreneurship course at degree level. The students were selected due to their enrolment in Entrepreneurship program which provide an indication that their career interest is skewed toward business related field (Zainuddin \& Ismail, 2011), therefore they would likely choose to become entrepreneurs. The research population comprised of 467 students undertaking a degree in entrepreneurship in both private and public Universities main campuses in Kenya.

Table 1. Population Total: 467.

\begin{tabular}{ll}
\hline Name of University & Number of Students \\
\hline University of Eldoret & 58 \\
Jomo Kenyatta University & 180 \\
Kisii University & 30 \\
Egerton University & 48 \\
Pwani University & 29 \\
Moi University & 56 \\
Karatina University & 34 \\
Kenya Methodist University & 32 \\
\hline
\end{tabular}

\subsection{Sample Size and Sampling Procedure}

Sampling is the process of selection of sampling units from the population to estimate population parameters in such a way that the sample will represent the population (Gall \& Borg, 2007). In this study, the unit of analysis was all fourth year university students pursuing a degree in entrepreneurship.

A simple random sampling technique was used to obtain a representative sample. According to Mugenda and Mugenda, (2008) this technique ensures that each member has an equal chance of being selected. The sample is sufficient enough to represent the entire population as Mugenda and Mugenda has recommended that a $20-30 \%$ sample of a population is sufficient. The following recommended formula was used to determine the sample size:

$$
\mathrm{n}=\frac{N Z^{2} p q}{E^{2}(N-1)+Z^{2} p q}
$$

Where $\mathrm{n}=$ required sample size

$\mathrm{N}=$ Population size

$\mathrm{Pq}=$ population proportions $(0.5)$

$\mathrm{Z}=$ Is the value that specifies the level of confidence, the confidence interval that the researcher used to analyze the data, in this case the interval data is $(Z=1.96)$, for a confidence level of $95 \%$

$E^{2}=$ is the accuracy of the sample proportion of the individuals, in this case $\mathrm{E}$ is 0.05 .

Table 2. Sample size: 238.

\begin{tabular}{llll}
\hline Name of University & No. students & Percentage & Sample size \\
\hline University of Eldoret & 58 & $12 \%$ & 33 \\
Jomo Kenyatta University & 180 & $39 \%$ & 54 \\
Kisii University & 30 & $6.4 \%$ & 22 \\
Egerton University & 48 & $10.3 \%$ & 29 \\
Pwani University & 29 & $6.2 \%$ & 21 \\
Moi University & 56 & $12 \%$ & 32 \\
Karatina University & 34 & $7.3 \%$ & 24 \\
Kenya Methodist & 32 & $7 \%$ & 23 \\
\hline University & & &
\end{tabular}

Source: Tigers Algebra 2010:

\subsection{Data Collection Instrument}

The purpose of a research instrument is to measure the variables of the study (Mugenda \& Mugenda, 2008). It is the process of gathering data from the sample so that research questions can be answered (Bryman, 2012). In this study questionnaire with closed ended questions and open-ended questions were used. Self administered questions are more convenient for respondents because they can complete them when they want and at their speed (Bryman \& Bell, 2015). Questionnaires have less reactivity effect or interviewer biased that can be created by the presence of the researcher (Gorard, 2004).

In this study, questionnaires were used to collect primary data. This is because they help in providing first hand information. The open ended questions were used so that the responded can freely express themselves while the closed ended questions allowed the respondent to give answers in a certain order. Since the respondents were literate, a questionnaire was quite adequate.

\subsection{Validity and Reliability}

Pilot testing is the start phase in data gathering of the research process. It is conducted to detect weaknesses in design and instrument and to provide alternative data for selection of a probability sample (Cooper \& Schindler, 2011). A pilot test was carried out in order to measure the reliability and validity of the research instruments (Kothari, 2008). The 
purpose of pilot testing is to detect weaknesses in design and implementation and to provide proxy for data collection of probability sample (Cooper \& Schindler, 2011). Pilot testing played a vital role in establishing the accuracy and appropriateness of the research design and instrumentation and in providing proxy data for selection of probability sample (Saunders, Lewis \& Thornhill, 2009). Bryman and Bell (2015) state that pilot test respondents should be comparable to members of the population from which the sample for the full study is taken. To test the reliability and validity of the instrument, the researcher conducted a pilot study to University students that are not part of the population under study but have undertaken an entrepreneurship course at one point.

\subsection{Data Analysis and Reporting}

According to Mugenda and Mugenda (2008), the term analysis refers to the communication of certain measures along with searching for a pattern of relationship that existed among data groups. The researcher collected primary data by giving out questionnaires to the respondents which was later analyzed using SPSS. The purpose of data analysis was to summarize the collected data and organize it in a manner to answer research questions. The researcher later used percentage analysis, frequency distribution, and charts graphs. The chi-square model was used to analyze the collected data.

\subsection{Spearman's Rho Correlation Analysis}

Spearman's correlation coefficient is a statistical measure of the strength of a relationship between paired data. It is denoted by $r_{2}$. The closer $r_{2}$ is to +-1 , the stronger is the relationship. The calculation of the spearman's correlation coefficient and subsequent significance testing requires data that is ordinal and that is why it is a good test for this study.

When the value of $r_{2}=0$, it doesn't mean that the relationship between variables does not exist but on the contrary, it means that there is a correlation only that it is a quadratic relationship. Where the value $r=1$ means there is a perfect positive correlation and the value $r=-1$ means a perfect negative correlation does exist. Spearman's Rho is calculated using the formula:

\subsection{Friedman's Test for Ranking}

Friedman (2009) defined Friedman test as a nonparametric statistical test used to detect differences across multiple test attempts. The procedure involves ranking row (or block) together, then considering the values of ranks by columns. The use of ranks is to avoid the assumption of normality implicit in the analysis of variance. The results of the Friedman test were used to screen important variables that were then used in the chi-square analysis which examined the effect of entrepreneurship curriculum in inculcating an entrepreneurial intention among students. The students were asked to use a Likert - scale to rank their entrepreneurial intention.

\subsection{Chi-square Model}

The chi-square model was used to determine the effect of entrepreneurship education in inculcating entrepreneurial intention. The model has been used in the past by various researchers. Maertz and Zhang (2004) used it to test technology adoption, Acs \& Armington, (2002), gender, Booth, (2007). Chi- square is applied when they are two categorical variables from a single population. It is used to determine whether there is a significant association between the two variables. Chi- square is also used when the sampling method is a simple random sampling, when the variables under study are each categorical and also when the sample data are displayed in a contingency table and the expected frequency count for each cell of the table is at least five. Using sample data the test statistic is used to find the degree of freedom, expected frequencies, list statistics and the pvalue associated with the test statistics.

The degree of freedom (DF) is equal to; $-\mathrm{DF}=(\mathrm{R}-1)(\mathrm{c}-1)$ where $r$ is, the number of level for one categorical variable and $\mathrm{C}$ is the number of levels for the other categorical variable.

The test statistic Chi-square random variable $\left(\chi^{2}\right)$ is defined by

$$
x^{2}=\frac{\Sigma(0-E)^{2}}{E^{2}}
$$

\subsection{Gender of Respondents}

Majority of respondents were female represented by $53.80 \%$ as opposed to $46.20 \%$ of males. This shows that most of the respondents were female and they are about $7.60 \%$ over the males.

\section{Entrepreneurship Curriculum on Entrepreneurial Intention}

\subsection{Skill Acquisition and Entrepreneurial Intention}

The study found that Entrepreneurial Intention of entrepreneurship students could be influenced by the skills acquired in course of study of the respondents. This was noted after collecting, summarizing and analyzing data and by doing cross tabulations in SPSS skill acquisition and Entrepreneurial intention. The relationship was found to be statistically significant. Pearson Chi-Square $\left(\chi^{2}\right)$ was the test statistic that was used to establish this. The summary in Table 3 shows that the value of Pearson Chi-Square $\left(\chi^{2}\right)$ from the sample data was 10.785 , and the respective probability value (P-Value) in the asymptotic significance column is 0.03 which is less than the significance level 0.05 This means that there's no $0 \%$ chance to find the observed (or a larger) degree of association between the variables if they are perfectly independent in the population and so the rule of inference was that this relationship was statistically significant. Acquisition of Entrepreneurship skills therefore had a statistically significant influence on Entrepreneurial Intention among entrepreneurship University students. 
Table 3. Skill acquisition and entrepreneurial intention.

\begin{tabular}{llll}
\hline Test statistic & Value & $\begin{array}{l}\text { Degrees of } \\
\text { freedom }\end{array}$ & $\begin{array}{l}\text { Asymptotic } \\
\text { Significance. (2-sided) }\end{array}$ \\
\hline $\begin{array}{l}\text { Pearson Chi-Square } \\
\text { Likelihood Ratio }\end{array}$ & $\begin{array}{l}10.785 \\
7.393\end{array}$ & 3 & 0.03 \\
$\begin{array}{l}\text { Linear-by-Linear } \\
\text { Association }\end{array}$ & 0.001 & 1 & 0.01 \\
No. of Valid Cases & 212 & & 0.970 \\
\hline
\end{tabular}

\subsection{Starting a Venture and Entrepreneurial Intention}

The study found that Entrepreneurial intention of entrepreneurship students could be influenced by their ability to start their own venture. This was as noted after collecting, summarizing and analyzing data and by doing cross tabulations in SPSS for preparation of students to start their own venture and Entrepreneurial Intention among Entrepreneurship students. The relationship was found to be statistically significant. Pearson Chi-Square $\left(\chi^{2}\right)$ was the test statistic that was used to establish this. The summary in Table 4 shows that the value of Pearson Chi-Square statistic (from the sample data was 5.287, and the respective probability value (P-Value) in the asymptotic significance column is 0.031 which is less than the significance level, 0.05 or $5 \%$. This means that there's no $0 \%$ chance to find the observed (or a larger) degree of association between the variables if they are perfectly independent in the population and so the rule of inference was that this relationship was statistically significant. It means therefore entrepreneurship Curriculum helps students prepare to start their own venture had a statistically significant influence on Entrepreneurial Intention.

Table 4. Starting a venture and entrepreneurial intention

\begin{tabular}{llll}
\hline Test statistic & Value & $\begin{array}{l}\text { Degrees of } \\
\text { freedom }\end{array}$ & $\begin{array}{l}\text { Asymptotic } \\
\text { Significance. (2-sided) }\end{array}$ \\
\hline Pearson Chi-Square & 5.287 & 12 & .0310 \\
Likelihood Ratio & 7.258 & 12 & .840 \\
Linear-by-Linear & .000 & 1 & .993 \\
Association & 212 & & \\
No. of Valid Cases & 212 & \\
\hline
\end{tabular}

\subsection{Entrepreneurship Curriculum too Theoretical or Practical and Entrepreneurial Intention}

The study found that Entrepreneurial intention of entrepreneurship students could be influenced by the curriculum offered in the course of study of the respondents. This was as noted after collecting, summarizing and analyzing data and by doing cross tabulations in SPSS for Entrepreneurship Curriculum testing whether it was too theoretical too practical and its effect in inculcating Entrepreneurial Intention among selected entrepreneurship students who enrolled in entrepreneurship class. The relationship was found to be statistically significant. Pearson Chi-Square $\left(\chi^{2}\right)$ was the test statistic that was used to establish this. The summary in Table 3 below shows that The value of Pearson Chi-Square statistic (from the sample data was 0.607 , and the respective probability value (P-Value) in the asymptotic significance column is 0.023 which is less than the significance level, 0.05 or $5 \%$, This means that there is $0 \%$ chance to find the observed (or a larger) degree of association between the variables if they are perfectly independent in the population and so the rule of inference was that this relationship was statistically significant. From the findings, Entrepreneurship Curriculum is too theoretical and lacks practical application.

Table 5. Theoretical or practical Entrepreneurship curriculum and entrepreneurial intention.

\begin{tabular}{llll}
\hline Test statistic & Value & $\begin{array}{l}\text { Degrees of } \\
\text { freedom }\end{array}$ & $\begin{array}{l}\text { Asymptotic } \\
\text { Significance. (2-sided) }\end{array}$ \\
\hline Pearson Chi-Square & $.607^{\mathrm{a}}$ & 3 & 0.023 \\
Likelihood Ratio & .538 & 3 & 0.911 \\
$\begin{array}{l}\text { Linear-by-Linear } \\
\text { Association }\end{array}$ & .143 & 1 & 0.706 \\
No. of Valid Cases & 212 & & \\
\hline
\end{tabular}

\subsection{Contribution of Entrepreneurship Curriculum in Inculcating Entrepreneurial Mindset}

The study found that an Entrepreneurial curriculum contributes in influencing an entrepreneurial mindset among entrepreneurship students. This was as noted after collecting, summarizing and analyzing data and by doing cross tabulations in SPSS for inculcating an entrepreneurial mindset among entrepreneurship students. The relationship was found to be statistically significant. Pearson Chi-Square $\left(\chi^{2}\right)$ was the statistic that was used to establish this. The summary in Table 5 shows that the value of Pearson ChiSquare statistic (from the sample data was 4.147, and the respective probability value (P-Value) in the asymptotic significance column is 0.033 which is less than the significance level, 0.05 or $5 \%$. This means that there's no $0 \%$ chance to find the observed (or a larger) degree of association between the variables if they are perfectly independent in the population and so the rule of inference was that this relationship was statistically significant. In other words, curriculum on creating an entrepreneurial mindset had a statistically significant influence on Entrepreneurial Intention.

Table 6. Creating an entrepreneurial mindset and inculcating an entrepreneurial intention among University Entrepreneurship students.

\begin{tabular}{llll}
\hline Test statistic & Value & $\begin{array}{l}\text { Degrees of } \\
\text { freedom }\end{array}$ & $\begin{array}{l}\text { Asymptotic } \\
\text { Significance. (2-sided) }\end{array}$ \\
\hline Pearson Chi-Square & 4.147 & 3 & .033 \\
Likelihood Ratio & 4.087 & 3 & .252 \\
Linear-by-Linear & 2.647 & 1 & .104 \\
Association & 212 & & \\
No. of Valid Cases & 212 & \\
\hline
\end{tabular}

\subsection{Statistical Significance of Correlation Between Entrepreneurship Education [Curriculum] on Entrepreneurial Intention}

Table 7 was used to illustrate statistical significance between Entrepreneurship Education and how it influences entrepreneurial intention among university students in Kenya. The value of correlation coefficient gave a hint how a change in one variable (dependent) is influenced by a change in another variable (independent) or it measures the association 
between variables (how an increase or decrease in one variable influences another variable). Spearman's rho correlation coefficient is mostly applicable whenever the variables in question are categorical (measurable on either nominal or ordinal scale of measurement). Table 6 shows a summary of Spearman's rho correlation coefficient, after sample data was collected, coded, and analyzed in SPSS software and from table 7, The value of correlation coefficient is significant at $p=0.01$ significance level (with double asterisk) and the value of correlation coefficient is significant at $p=0.05$ significance level (with single asterisk)

Table 7. Spearman's rho (p) correlation of Entrepreneurship Education Curriculum and Entrepreneurial Intention.

\begin{tabular}{|c|c|c|}
\hline & Significance & $\begin{array}{l}\text { Entrepreneurial } \\
\text { Intention }\end{array}$ \\
\hline \multirow{3}{*}{$\begin{array}{l}1 \text { The entrepreneurship } \\
\text { education has helped you acquire } \\
\text { skills }\end{array}$} & $\begin{array}{l}\text { Correlation } \\
\text { Coefficient }\end{array}$ & 0.063 \\
\hline & Sig. (2-tailed) & 0.365 \\
\hline & $\mathrm{N}$ & 212 \\
\hline \multirow{3}{*}{$\begin{array}{l}2 \text { To what extent have you } \\
\text { acquired the necessary skills to } \\
\text { start an enterprise }\end{array}$} & $\begin{array}{l}\text { Correlation } \\
\text { Coefficient }\end{array}$ & -0.01 \\
\hline & Sig. (2-tailed) & 0.883 \\
\hline & $\mathrm{N}$ & 212 \\
\hline \multirow{3}{*}{$\begin{array}{l}3 \text { To what extent would you say } \\
\text { that University entrepreneurship } \\
\text { education helps in business idea } \\
\text { generation }\end{array}$} & $\begin{array}{l}\text { Correlation } \\
\text { Coefficient }\end{array}$ & $0.771^{*}$ \\
\hline & Sig. (2-tailed) & 0.778 \\
\hline & $\mathrm{N}$ & 212 \\
\hline \multirow{3}{*}{$\begin{array}{l}4 \text { The University } \\
\text { Entrepreneurship Curriculum is } \\
\text { too theoretical }\end{array}$} & $\begin{array}{l}\text { Correlation } \\
\text { Coefficient }\end{array}$ & 0.037 \\
\hline & Sig. (2-tailed) & 0.596 \\
\hline & $\mathrm{N}$ & 212 \\
\hline \multirow{3}{*}{$\begin{array}{l}5 \text { To what extent do you agree } \\
\text { with the statement that } \\
\text { entrepreneurship facilitates } \\
\text { economic growth }\end{array}$} & $\begin{array}{l}\text { Correlation } \\
\text { Coefficient }\end{array}$ & $0.862^{* *}$ \\
\hline & Sig. (2-tailed) & 0.601 \\
\hline & $\mathrm{N}$ & 212 \\
\hline \multirow{3}{*}{$\begin{array}{l}6 \text { Entrepreneurship Education } \\
\text { does not help students change } \\
\text { their perception about self- } \\
\text { employment }\end{array}$} & $\begin{array}{l}\text { Correlation } \\
\text { Coefficient }\end{array}$ & 0.12 \\
\hline & Sig. (2-tailed) & 0.081 \\
\hline & $\mathrm{N}$ & 212 \\
\hline \multirow{3}{*}{$\begin{array}{l}7 \text { What duration should a student } \\
\text { take to study and have their } \\
\text { intention changed }\end{array}$} & $\begin{array}{l}\text { Correlation } \\
\text { Coefficient }\end{array}$ & -0.075 \\
\hline & Sig. (2-tailed) & 0.277 \\
\hline & & 212 \\
\hline
\end{tabular}

\section{Conclusion}

Given the findings in this study, the study agrees with various past studies that entrepreneurship education has a positive effect in inculcating entrepreneurial intention. Given the fact that Entrepreneurship plays a very key role in economic development, it leaves the higher learning institution with a task of improving its pedagogy and aligning it with the trending issues in the country to make it applicable and relevant. Entrepreneurship Education program should be viewed positively and then be implemented at all levels of learning in Kenya. Entrepreneurship Education should be tailored to make a person more competent and more professionalized business owner. Just like Lawrence
Summers, former president of Harvard University once said "Anything you learn is going to become obsolete within a decade and so the most important kind of learning is about how to learn"

\section{Recommendations}

In a global economy plagued by high levels of unemployment nothing would be better than helping students launch their own businesses. Students can be encouraged to conduct market research, obtain finance and create viable businesses. The entrepreneurship students would practically learn in the process and other students expand their practical knowledge. Universities can come up with entrepreneurship courses that are more engaging and make money by providing consulting services to small businesses and nonprofit agencies. Conceptually entrepreneurship lecturer may lead the consulting team of students by formulating operational priorities and guide students throughout to consulting engagement. This scenario offers a win-win for all parties involved Students learn practical stuff on how to cope with businesses and non-profit agencies pay affordable rates for high quality consulting services from the students.

\section{Research Suggestions}

Since entrepreneurship is taught as a unit across the board to students taking other courses, future researchers can investigate how much the students are prepared to engage in enterprise creation upon graduation. This research was based on Entrepreneurship University students, future researchers may focus on students in polytechnic colleges, Organizations that carry out entrepreneurship training and investigate the effect of such training and how it inculcates an entrepreneurial culture among organizational employees.

\section{References}

[1] Acs, Z., \& Armington, C. (2004). Employment growth and entrepreneurial activity in cities. Regional Studies, 38(8), 911927.

[2] Booth, A. L. (2007). The Glass Ceiling in Europe: Why are Women Doing Badly in the Labour.

[3] Bryman, A. (2012). Social research methods. Oxford: Oxford university press.

[4] Bryman, A., \& Bell, E. (2015). Business research methods. Oxford: Oxford university press.

[5] Burns, p. (2007). Entrepreneurship and Small Business. Entrepreneurship, 67. Business Education Research 2(1): 2747.

[6] Choo, 2000. Study of effective entrepreneurship education method and its process.

[7] Cooper, D. R., \& Schindler, P. S. (2011). Business research methods, $12^{\text {th }}$ Ed. Boston: McGraw-Hill Higher Education. 
[8] European Conference on Entrepreneurship and Innovation, \& Breat, J. (2009). The proceedings of the $4^{\text {th }}$.

[9] European conference on entrepreneurship and innovation: [book of abstracts]. Antwerp: University of UK, 15-16 September 2008. Reading: Academic Publishers.

[10] Fayolle, A. (2007). Handbook of research in entrepreneurship education: Volume 1. Cheltenham, UK: Edward Elgar.

[11] Fiet, J. O. (2002). Entrepreneurial discovery.

[12] Friedman, B. M. (2009). Widening inequality combined with modest growth. Challenge 52(3), 76-91.

[13] Gall, M. D., Gall, J. P., \& Borg, W. R. (2007). Collecting research data with questionnaires and interviews. Educational research: an introduction, 227-261.

[14] Gibb, A. and Hannon, P. (2006). Towards the entrepreneurial University. International Journal of entrepreneurship Education, 4(1), 73-110.

[15] Gorard, S. (2004). Quantitative methods in social science. London: Continuum.

[16] Katz, J. A (2003). The chronology and intellectual trajectory of American Entrepreneurship education" journal of business venturing. 18(2) 283-300 chapter 2.

[17] Kirby, D. (2003). Entrepreneurship. London: McGraw-Hill.

[18] Kothari, C. R. (2008). Research methodology: Methods \& techniques. New Delhi: New Age International (P) Ltd.

[19] Koratko, D. F. (2005). The emergence of entrepreneurship education: Development trends, and challenges, entrepreneurship theory and practice, 29 (5), 577-597Kuratko, D. F. (2014). Entrepreneurship Theory, process, practice (9thed). Mason, OH: Cengage publishing. Kombo, D. (19).

[20] Tromp, D. L. (2006). Research methodology. New Delhi: Wiley Eastern Ltd.

[21] Leyden, D. P., \& Link, A. N. (2015). Public sector entrepreneurship: U.S. technology and innovation policy.

[22] Maertz, C. P. (2004). Five antecedents neglected in employee turnover models: Identifying theoretical linkages to turnover for personality, culture, organizational performance, occupational attachment, and location attachment. Innovative theory and empirical research on employee turnover, 105-152.

[23] Matlay, H. (2005). The impact of resource on SMEs: Critical perspective. Bradford, England: Emerald Group Pub. Antwerp.

[24] Mugenda, O. M., \& Mugenda, A. G. (2008). Research Methodology, Qualitative and Quantitative Methods. Nairobi: Acts Press.
[25] Nabi, G., Holden., R., and Walmsley, A. (2006). Careermaking; Graduating into self employment, National Council for graduate entrepreneurs. Research Report 009/2006. Leeds: Leeds metropolitan University.

[26] Nachmias, C., \& Nachmias, D. (2008). Research methods in the social sciences, $7^{\text {th }}$ ed. New York: Worth Publishers.

[27] Nelson Murungu Kenya Rural Enterprise Programme. (2002). Jua kali literature: An annotated bibliography. Nairobi: The Programme.

[28] Noel, T. (2001). Effects of Entrepreneurial Education on intent to open a business. Wichita State University.

[29] Oviawe, J. O. (2010). Repositioning Nigerian Youths for economic empowerment through Entrepreneurship education. European journal of education studies, 2 (2), 113-118.

[30] Oyugi, J. L. (2015). Entrepreneurship education, self efficacy and intentions. Saarbrücken: LAP LAMBERT Academic Publishing.

[31] Pinar, William F. (2011). The character of curriculum studies. Building, Currere and the recurring questions of the subject. New York Palgrave Macmillan.

[32] GoK. (2006) Vision 2030. Nairobi. Government Printers. Repbulic of Kenya.

[33] Rubin, A., \& Babbie, E. R. (2010). Essential research methods for social work. Belmont, CA: Brooks/Cole, Cengage Learning.

[34] Saunders, M., Lewis, P., \& Thornhill, A. (2009). Research methods for business students. New York: Prentice Hall.

[35] Solomon, G. T., and Fernald. L. (1991). Trends in Small business management and entrepreneurship education in the United States. Entrepreneurship Theory and practice, 15(3) 25-40.

[36] Timmons, J. A., Spinelli, S., \& Tan, Y. (2012). New venture creature: Entrepreneurship for the 21st century. Singapore: McGraw-Hill Education (Asia).

[37] Weber, S. (2014). Becoming an entrepreneur.

[38] Zainuddin, M. N., \& Ismail, H. (2011). Push and pull factor in an entry into an employment route: a study of nurtured entrepreneurship students. International Journal of Entrepreneurship and Small Business, 13(4), 469-498.

[39] Zainuddin, M. N., \& Ismail, H. (2011). Push and pull factor in an entry into an employment route: a study of nurtured entrepreneurship students. International Journal of Entrepreneurship and Small Business, 13(4), 469-498. 